\title{
Horse Lymphoma
}

National Cancer Institute

\section{Source}

National Cancer Institute. Horse Lymphoma. NCI Thesaurus. Code C134778.

Lymphoma that occurs in a horse. 